\title{
Extraction/export of nutrients in Opuntia ficus-indica under different spacings and chemical fertilizers
}

\author{
João A. da Silva ${ }^{1}$, Sérgio L. R. Donato ${ }^{1}$, Paulo E. R. Donato ${ }^{1}$, Evilasio dos S. Souza ${ }^{1}$, \\ Milton C. Padilha Júnior ${ }^{1} \&$ Ancilon A. e Silva Junior ${ }^{1}$

\begin{abstract}
${ }^{1}$ Instituto Federal de Educação, Ciência e Tecnologia Baiano. Guanambi, BA. E-mail: joao.silva@guanambi.ifbaiano.edu.br (Corresponding author); sergio.donato@guanambi.ifbaiano.edu.br; paulo.donato@guanambi.ifbaiano.edu.br; evilasiomutans@hotmail.com; padilhajrmc@gmail.com; ancilon. silva@guanambi.ifbaiano.edu.br
\end{abstract}

\section{Key words: \\ Opuntia \\ nutrient uptake \\ concentration \\ NPK fertilization}

\begin{abstract}
A B S T R A C T
This work aimed to evaluate extraction/export of nutrients and dry matter production in the 'Gigante' cactus pear, grown in different spacings and fertilizations 620 days after planting. Twelve combination of treatments were used consisting of: three spacings - $1.00 \mathrm{x} 0.50$; $2.00 \times 0.25$; and $3.00 \times 1.00 \times 0.25 \mathrm{~m}$, and four fertilizations - 000-000-000; 000-150-000; 200-150-000; and 200-150-100, $\mathrm{kg} \mathrm{ha}^{-1}$, of N, $\mathrm{P}_{2} \mathrm{O}_{5}$ and $\mathrm{K}_{2} \mathrm{O}$, in a $3 \times 4$ factorial scheme in a randomized block design, with three replicates. Extraction/export of N, P, K, S, Ca, Mg, B, $\mathrm{Fe}, \mathrm{Mn}, \mathrm{Zn}, \mathrm{Na}$ and $\mathrm{Cu}$ were determined and the means were $304.35 ; 18.81 ; 421.04 ; 62.35$; $464.63 ; 215.77 ; 0.39 ; 0.81 ; 23.74 ; 1.11 ; 0.62$ and $0.08 \mathrm{~kg} \mathrm{ha}^{-1}$, besides the mean dry matter production of $17.11 \mathrm{Mg} \mathrm{ha}^{-1}$. There were significant interactions for extraction/export of $\mathrm{Mg}$ and dry matter production. The fertilizations used were insufficient to meet the demand of $\mathrm{N}, \mathrm{K}, \mathrm{Ca}, \mathrm{Mg}, \mathrm{S}$ and micronutrients. Fertilization increased the extraction of nutrients, particularly N, P and $\mathrm{S}$ at the spacing of $1.00 \times 0.50 \mathrm{~m}$, and increased dry matter production. The decreasing order of extraction/export was $\mathrm{Ca}, \mathrm{K}, \mathrm{N}, \mathrm{Mg}, \mathrm{S}$ and $\mathrm{P}$ for macronutrients and $\mathrm{Mn}, \mathrm{Zn}, \mathrm{Fe}, \mathrm{Na}, \mathrm{B}$ and $\mathrm{Cu}$ for micronutrients.
\end{abstract}

\section{Palavras-chave:}

Opuntia

absorção de nutrientes

concentração

fertilização NPK

\section{Extração/exportação de nutrientes pela palma forrageira 'Gigante' em diferentes espaçamentos e adubações químicas}

\section{R E S U M O}

Objetivou-se, com este trabalho, avaliar extração/exportação de nutrientes e produção de matéria seca na palma forrageira 'Gigante', cultivada em diferentes espaçamentos e adubações aos 620 dias após o plantio. Foram utilizados 12 combinações de tratamentos consistindo de: três espaçamentos, $1,00 \times 0,50 ; 2,00 \times 0,25 ;$ e 3,00 x 1,00 x 0,25 m, e quatro adubações, 000-000-000; 000-150-000; 200-150-000; e 200-150-100, kg ha ${ }^{-1}$, de N, $\mathrm{P}_{2} \mathrm{O}_{5}$ e $\mathrm{K}_{2} \mathrm{O}$, dispostos em fatorial $3 \times 4$, delineado em blocos casualisados, com três repetições. Determinaram-se: extração/exportação de: N, P, K, S, Ca, Mg, B, Fe, Mn, Zn, Na e Cu, cujas médias foram: 304,$35 ; 18,81 ; 421,04 ; 62,35 ; 464,63 ; 215,77 ; 0,39 ; 0,81 ; 23,74 ; 1,11 ; 0,62 ; 0,08$ $\mathrm{kg} \mathrm{ha}^{-1}$ e produção de matéria seca média de $17,11 \mathrm{Mg} \mathrm{ha}^{-1}$. Houve interações significativas para a extração/exportação de $\mathrm{Mg}$ e produção de matéria seca. As adubações não atenderam às quantidades extraídas/exportadas de $\mathrm{N}, \mathrm{K}, \mathrm{Ca}, \mathrm{Mg}$ nem dos micronutrientes. As adubações elevaram as extrações principalmente de $\mathrm{N}, \mathrm{P}$ e $\mathrm{S}$, no espaçamento 1,00 x 0,50 m e aumentaram a produção de matéria seca. A ordem decrescente de extração/exportação de macronutrientes foi $\mathrm{Ca}, \mathrm{K}, \mathrm{N}, \mathrm{Mg}$, S e P e de micronutrientes $\mathrm{Mn}, \mathrm{Zn}, \mathrm{Fe}, \mathrm{Na}, \mathrm{B}$ e $\mathrm{Cu}$. 


\section{INTRODUCTION}

Cactus pear represents a fundamental feed support for cattle in the Brazilian semiarid region, because it tolerates long drought periods of up to five months, maintaining its photosynthetic activity (Zañudo-Hernández et al., 2010). With the cultivation of approximately 600 thousand hectares, Brazil has the largest planted area of cactus pear in the world, where the species Opuntia fícus-indica prevails, known as 'Gigante' cactus pear (Araújo et al., 2005). Currently, the cultivation of this species is in expansion in the semiarid region of the states of Bahia and Minas Gerais, intensified by the severe drought of 2012 and 2013.

The correct conduction of the cultivation demands the use of adequate techniques in the search of higher yields, better quality and longevity of the cactus field. Plant population must vary according to soil fertility, amount of rainfall, type of exploration and species or cultivar used. Spacing and fertilization managements can improve the use of radiation and the nutritional status of plants (Blanco-Macías et al., 2010) with the increment in photosynthetic rate, growth, yield and, consequently, in the nutritional value of the produced forage (Silva et al., 2013; Donato et al., 2014b). Espinoza et al. (2008), working with five cultivars in Mexico, reported that significant increases in the production of green and dry matter can be obtained with the use of dense plantation. Ramos et al. (2011) concluded that spacing influences phytomass production per area and the efficiency of the use of rainfall, with higher increments for increasing densities. Such result was also reported by Silva et al. (2014). The influence of fertilization on yield is demonstrated by Stewart et al. (2005), who analyzed results of 362 crop production seasons and verified that 30 to $50 \%$ of the yields of the evaluated crops are attributed to nutrients of commercial fertilizers containing mainly N, P and K. Silva et al. (2013) claim that the addition of NPK and NP fertilization resulted in improvement of the nutritional quality of cactus pear and, at the spacing of $1.00 \mathrm{x}$ $0.50 \mathrm{~m}$, in the increase of dry matter production, at 620 days after planting. Santos et al. (2006) highlight that organic or mineral fertilization can increase by more than $100 \%$ cactus pear production and that, two years after planting, the dense cultivation promoted production of 250 to $300 \mathrm{Mg} \mathrm{ha}^{-1}$ of green matter, but it requires high fertilization levels and greater care with respect to cultural practices. Cactus pear has high contents of $\mathrm{Ca}(3.74 \%), \mathrm{K}(1.83 \%)$ and $\mathrm{Mg}(2.14 \%)$ in the dry matter (Germano et al., 1999). As to the organic fertilization, Donato et al. (2014a) points out that the plant responds with yield increase up to the application of $71.8 \mathrm{Mg} \mathrm{ha}^{-1}$ year $^{-1}$ of cattle manure and that the increasing doses promoted increment of plant structural characteristics and improved the nutritive value of the cactus pear (Donato et al., 2014b). Donato (2011), with the use of $90 \mathrm{Mg} \mathrm{ha}^{-1}$ year $^{-1}$ of cattle manure and production of $20.9 \mathrm{Mg} \mathrm{ha}^{-1}$ of dry matter, observed extraction of $300,50,920$ and $630 \mathrm{~kg} \mathrm{ha}^{-1}$ for N, P, K and Ca, respectively.

The nutritional requirements of any plant are determined by the amount of nutrients that it extracts during its productive cycle. For a mean biannual yield of $40 \mathrm{Mg} \mathrm{ha}^{-1}$ of dry matter, cactus pear extracts about $360 \mathrm{~kg} \mathrm{ha}^{-1}$ of $\mathrm{N}, 64 \mathrm{~kg} \mathrm{ha}^{-1}$ of $\mathrm{P}$,
$1,032 \mathrm{~kg} \mathrm{ha}^{-1}$ of $\mathrm{K}$ and $940 \mathrm{~kg} \mathrm{ha}^{-1}$ of $\mathrm{Ca}$ (Dubeux Júnior \& Santos, 2005). Therefore, the total extraction of nutrients will depend on the obtained yield and on crop residues. In this crop, harvest removes virtually all the vegetative part, leaving only crop residues for incorporation to the soil. Thus, there is large extraction/export of nutrients, which compromises the sustainability and the resilience of the production system, especially in soils of semiarid regions (Fialho et al., 2013). As a consequence, fertility problems will worsen over time if a soil management system and adequate fertilizations are not adopted, because the crop remains in the same area for many years. The estimate of the amount of nutrients extracted by the plant and effectively transported allows the correct replenishment of these nutrients in order to maintain plant nutrition and adequate balance of input and output of nutrients in the system, to avoid the progressive decrease in soil fertility. Therefore, this study aimed to evaluate the extraction/export of nutrients and dry matter production of cactus pear under different spacings and chemical fertilization.

\section{Material ANd Methods}

The experiment was conducted at the Federal Institute of Bahia, Campus of Guanambi-BA, in a typical dystrophic Red Yellow Latosol, with weak A horizon, medium texture, under hypoxerophytic Caatinga and on flat to gently undulating topography. The coordinates are $14^{\circ} 13^{\prime} 30^{\prime \prime} \mathrm{S}$ and $42^{\circ} 46^{\prime} 53^{\prime \prime} \mathrm{W}$ at an altitude of $545 \mathrm{~m}$ and the climate is Aw, according to Köppen's classification, with annual means of $680 \mathrm{~mm}$ of rainfall and temperature of $26^{\circ} \mathrm{C}$.

The study consisted in the evaluation of the extraction/ export of macro and micronutrients 620 days after planting, by the 'Gigante' cactus pear (Opuntia fícus-indica Mill). The experiment was set in randomized blocks with 12 treatments arranged in a $3 \times 4$ factorial scheme, with three replicates. The first factor represented three spacings: a) single row 1.00 $\mathrm{x} 0.50 \mathrm{~m}$; b) single row $2.00 \times 0.25 \mathrm{~m}$ and c) double row, 3.00 $\mathrm{x} 1.00 \times 0.25 \mathrm{~m}$, maintaining the population density of 20,000 plants ha ${ }^{-1}$. The second factor represented four combinations of chemical fertilization: a) without chemical fertilization; b) phosphate $(\mathrm{P})$ fertilization at the dose of $150 \mathrm{~kg} \mathrm{ha}^{-1}$ of $\mathrm{P}_{2} \mathrm{O}_{5}$; c) Phosphate and nitrogen (PN) fertilization at the doses of $150 \mathrm{~kg} \mathrm{ha}^{-1}$ of $\mathrm{P}_{2} \mathrm{O}_{5}$ and $200 \mathrm{~kg} \mathrm{ha}^{-1}$ of $\mathrm{N}$ and d) Nitrogen, phosphate and potassium (NPK) fertilization at the doses of $200 \mathrm{~kg} \mathrm{ha}^{-1}$ of N, $150 \mathrm{~kg} \mathrm{ha}^{-1}$ of $\mathrm{P}_{2} \mathrm{O}_{5}$ and $100 \mathrm{~kg} \mathrm{ha}^{-1}$ of $\mathrm{K}_{2} \mathrm{O}$. The experimental plot had dimensions of $16 \times 4 \mathrm{~m}$ and evaluation area of $8.00 \times 2.00 \mathrm{~m}$, totaling 36 experimental units with total area of $2,304 \mathrm{~m}^{2}$.

After cleaning, 36 experimental units were delimited and soil samples were collected (layer of $0-20 \mathrm{~cm}$ ) in each plot for fertility characterization, which showed the following mean results: $\mathrm{pH}$ in water $=5.33 ;\left(\mathrm{P}=10.6 \mathrm{mg} \mathrm{dm}^{-3}\right) ;(\mathrm{K}=0.14 ; \mathrm{Na}$ $=0.1 ; \mathrm{Ca}=1.4 ; \mathrm{Mg}=0.9 ; \mathrm{Al}=0.1 ; \mathrm{H}+\mathrm{Al}=1.8 ; \mathrm{SB}=2.4 ; \mathrm{t}=2.6$ and $\left.\mathrm{T}=4.4 \mathrm{cmol}_{\mathrm{c}} \mathrm{dm}^{-3}\right) ;(\mathrm{V}=55.9$ and $\mathrm{m}=3.9 \%) ;(\mathrm{Cu}=0.3$; $\left.\mathrm{Fe}=7 ; \mathrm{Mn}=57.7 ; \mathrm{Zn}=2.0 \mathrm{mg} \mathrm{dm}^{-3}\right)$. After that, subsoiling was performed at $35 \mathrm{~cm}$ of depth, besides two harrowings and the opening of furrows, which were $0.30 \mathrm{~m}$ deep and spaced by $1.00 \mathrm{~m}$. 
Planting was performed in late September 2009, using one cladode per hole, placed in a vertical position and buried until approximately half of its length. The seedlings were obtained from a cactus pear cultivation of the Federal Institute of Bahia, Campus of Guanambi, with approximate weight of $1.0 \mathrm{~kg}$ and free from pests and diseases. After cutting and selection at the field, the plants were left, in the shade, for a period of 15 days for the healing of harvest injuries.

During the planting, phosphate fertilization was performed in each plot corresponding to this treatment, by applying 150 $\mathrm{kg} \mathrm{ha}^{-1}$ of $\mathrm{P}_{2} \mathrm{O}_{5}$, which is equivalent to the application of 5.33 $\mathrm{kg} \mathrm{plot}^{-1}$ of single superphosphate. Along the experiment, as top-dressing (200 kg ha-1 of $\mathrm{N}$ and $100 \mathrm{~kg} \mathrm{ha}^{-1}$ of $\left.\mathrm{K}\right), 6.4 \mathrm{~kg}$ of ammonium sulfate and $1.10 \mathrm{~kg}$ of potassium chloride were applied per plot, divided into four applications corresponding to $15,25,30$ and $30 \%$ of the total dose, respectively. The first application was performed on December 28, 2009, after the occurrence of rainfall and the existence of at least one cladode per plant; the second on February 23, 2010, 57 days after the first one, also with moist soil. The third and the fourth applications were performed on November 14 and December 27,2010 , respectively.

Weed control was initially performed using a hoe and, as plant grew, glyphosate $(200 \mathrm{~mL}$ in $20 \mathrm{~L}$ of water) was applied in a jet directed to crop interrows, according to the necessity. Pest control followed the recommendations described by Santos et al. (2006).

Cladode samples were collected for the determination of the contents of macro and micronutrients in the tissue at 620 days after planting (DAP). Cladodes were collected from the middle section of the plants in the evaluation area, totaling 20 samples (with approximately $25 \mathrm{~g}$ of mass of cladodes) per treatment. The collection was performed using a hole saw with diameter of $5 \mathrm{~cm}$ and depth of $4 \mathrm{~cm}$, adapted to a batterycharged drilling machine, which was activated on the cladode to remove a circular, uniform slice (sample). After collection, the samples were sliced and dried in a forced-air oven at $60{ }^{\circ} \mathrm{C}$ for $72 \mathrm{~h}$. Then, the samples were ground in a Wiley-type mill with sieve of $1.0-\mathrm{mm}$ mesh, identified and placed in plastic pots. After that, the samples were sent to the Laboratory of Soils of the Agriculture Research Company of Minas Gerais (Epamig), for the analytical procedures.

The contents of the following elements were determined: nitrogen $(\mathrm{N})$, phosphorus $(\mathrm{P})$, potassium $(\mathrm{K})$, sulfur $(\mathrm{S})$, calcium $(\mathrm{Ca})$ and magnesium $(\mathrm{Mg})$, expressed in dag kg-1; and boron $(\mathrm{B})$, iron $(\mathrm{Fe})$, manganese $(\mathrm{Mn})$, zinc $(\mathrm{Zn})$, sodium $(\mathrm{Na})$ and copper $(\mathrm{Cu})$, expressed in $\mathrm{mg} \mathrm{kg}^{-1}$.
Dry matter content was determined according to the methodology described by Silva \& Queiroz (2009). Harvest was performed preserving three of the primary cladodes; then, green matter production was calculated, after drying, thus obtaining the dry matter production (DMP) as a function of this content in the cladodes.

Extraction/export of nutrients by the cactus pear was calculated as a function of the dry matter production and the content of the element in the cladode, and expressed in $\mathrm{kg} \mathrm{ha}^{-1}$ for macronutrients $(\mathrm{N}, \mathrm{P}, \mathrm{K}, \mathrm{Ca}, \mathrm{Mg}$ and $\mathrm{S}$ ) and micronutrients (Cu, B, $\mathrm{Zn}, \mathrm{Fe}, \mathrm{Mn}$ and $\mathrm{Na}$ ).

The data were subjected to analysis of variance by $\mathrm{F}$ test at 0.05 probability level to verify the significance of the interactions between the tested factors. When significant, a follow-up analysis was performed and the means were compared by Tukey test at 0.05 probability level. In the absence of interactions, the effects of the main factors were studied and the analyses were performed using the program SAEG version 9.1, of the Federal University of Viçosa.

\section{Results AND Discussion}

Macronutrients - There were significant effects $(\mathrm{p}<0.05)$ with respect to the means of extraction/export $\left(\mathrm{kg} \mathrm{ha}^{-1}\right)$ of $\mathrm{N}, \mathrm{P}$ and $\mathrm{S}$ in relation to the different types of fertilization, regardless of the adopted planting spacing (Table 1).

Nitrogen - Fertilizations with N sources, NP and NPK, promoted increase in its concentration and availability in the soil and, consequently, higher extraction/export by the cactus pear, which showed similar means, 391.00 and $413.40 \mathrm{~kg} \mathrm{ha}^{-1}$ in this order, but higher than 180.20 and $232.80 \mathrm{~kg} \mathrm{ha}^{-1}$, resulting from the treatments without fertilization and with the use of only P, respectively. Donato (2011) found values ranging from 159.9 to $320.3 \mathrm{~kg} \mathrm{ha}^{-1}$, in response to the increase in the manure dose applied to the soil from 0 to $90 \mathrm{Mg} \mathrm{ha}^{-1}$ year $^{-1}$. In the present study, there was overall mean extraction/export of $177.88 \mathrm{~kg} \mathrm{ha}^{-1}$ of $\mathrm{N}$ for every $10 \mathrm{Mg} \mathrm{ha}^{-1}$ of produced dry matter, superior to the values of 131.6 and $90 \mathrm{~kg} \mathrm{ha}^{-1}$ of $\mathrm{N}$ for every $10 \mathrm{Mg} \mathrm{ha}^{-1}$ of dry matter observed by Donato (2011) and Santos et al. (2002), respectively.

Phosphorus - For the treatments P, NP and NPK, the extractions/exports of 20.16, 20.74 and $21.95 \mathrm{~kg} \mathrm{ha}^{-1}$ of $\mathrm{P}$, respectively, were similar to but higher than the extraction/ export of $12.37 \mathrm{~kg} \mathrm{ha}^{-1}$, obtained with the treatment without fertilization. Such differences, in comparison to the treatment without fertilization, are justified by the greater availability of $P$ due to the addition, which favored the increase in absorption by the plant. Evaluating P contents in cladodes, Silva et al.

Table 1. Extraction/export $\left(\mathrm{kg} \mathrm{ha}^{-1}\right)$ of nitrogen $(\mathrm{N})$, phosphorus $(\mathrm{P})$, potassium $(\mathrm{K})$, sulfur $(\mathrm{S})$ and calcium $(\mathrm{Ca})$ in a cactus pear field, harvested 620 days after planting, under different spacings and chemical fertilizations

\begin{tabular}{cccccc}
\hline Fertilizations & \multicolumn{5}{c}{ Extraction/Export $\mathbf{k g ~ h a}^{-1}$ ) } \\
\cline { 2 - 6 } $\mathbf{N}-\mathbf{P}_{\mathbf{2}} \mathbf{O}_{\mathbf{5}}-\mathbf{K}_{\mathbf{2}} \mathbf{O}\left(\mathbf{k g ~ h a}^{-1}\right.$ year $\left.^{-1}\right)$ & Nitrogen & Phosphorus & Potassium & Sulfur & Calcium \\
$000-000-000$ & $180.20 \mathrm{~B}$ & $12.37 \mathrm{~B}$ & $393.72 \mathrm{~A}$ & $17.12 \mathrm{~B}$ & $444.07 \mathrm{~A}$ \\
$000-150-000$ & $232.80 \mathrm{~B}$ & $20.16 \mathrm{~A}$ & $401.44 \mathrm{~A}$ & $31.29 \mathrm{~B}$ & $505.06 \mathrm{~A}$ \\
$200-150-000$ & $391.00 \mathrm{~A}$ & $20.74 \mathrm{~A}$ & $384.98 \mathrm{~A}$ & $100.53 \mathrm{~A}$ & $431.89 \mathrm{~A}$ \\
$200-150-100$ & $413.40 \mathrm{~A}$ & $21.95 \mathrm{~A}$ & $504.01 \mathrm{~A}$ & $100.51 \mathrm{~A}$ & $476.71 \mathrm{~A}$ \\
Mean & 304.35 & 18.81 & 421.04 & 62.35 & 464.63 \\
CV (\%) & 20.12 & 22.79 & 24.87 & 23.43 & 19.84 \\
\hline
\end{tabular}

Means followed by the same uppercase letter in the column do not differ significantly by Tukey test at 0.05 probability level 
(2012) did not observe differences for the treatments P, NP and NPK. With mean value of $10.99 \mathrm{~kg} \mathrm{ha}^{-1}$ for every $10 \mathrm{Mg} \mathrm{ha}^{-1}$ of produced dry matter, the value of $\mathrm{P}$ extraction/export is lower than 19.4 and $16 \mathrm{~kg} \mathrm{ha}^{-1}$ for every $10 \mathrm{Mg} \mathrm{ha}^{-1}$ of produced dry matter obtained by Donato (2011) and Santos et al. (2002), respectively. Acoording to Donato (2011) organic fertilization promotes higher availability and mobility of $\mathrm{P}$ in the soil, compared with chemical fertilization.

Potassium - With mean of $421.04 \mathrm{~kg} \mathrm{ha}^{-1}$, the extraction/ export of $\mathrm{P}$ did not differ between treatments $(\mathrm{p}>0.05)$. This result can be explained by the small addition promoted by the NPK treatments $\left(100 \mathrm{~kg} \mathrm{ha}^{-1}\right.$ of $\left.\mathrm{K}_{2} \mathrm{O}\right)$. According to Silva et al. (2013), such added amount of $\mathrm{K}$ is insufficient to alter significantly $\mathrm{K}$ contents in the tissues. Furthermore, the soil already has, before planting, mean content of available $\mathrm{K}$ of $53.8 \mathrm{mg} \mathrm{dm}^{-3}$, equivalent to $129.63 \mathrm{~kg} \mathrm{ha}^{-1}$ of $\mathrm{K}_{2} \mathrm{O}$ plus nonexchangeable $\mathrm{K}$. The mean value of $421.04 \mathrm{~kg} \mathrm{ha}^{-1}$ obtained in the present study is lower than the mean results of $714.5 \mathrm{~kg} \mathrm{ha}^{-1}$ at 600 days and $1,032 \mathrm{~kg} \mathrm{ha}^{-1}$ every two years, obtained by Dubeux Júnior \& Santos (2005) and Donato (2011), respectively. Despite the mean contents of $\mathrm{K}$ in the soil and the low amount applied as fertilizer, the replenishment to the solution, through the reserve of the soil solid phase, as $\mathrm{K}$ is absorbed from the solution (Novais \& Mello, 2007) maintains plant production; however, the extraction is low, a reflex of the availability.

Calcium - The extraction/export of Ca resulting from the treatments without fertilization, with P, NP and NPK did not differ ( $p>0.05)$. In the present study, Ca was the most extracted nutrient ( $464.63 \mathrm{~kg} \mathrm{ha}^{-1}$ ), equivalent to $271.55 \mathrm{~kg} \mathrm{ha}^{-1}$ for every $10 \mathrm{Mg} \mathrm{ha}^{-1}$ of produced dry matter. It is an intermediate value in relation to 300.7 and $235 \mathrm{~kg} \mathrm{ha}^{-1}$ for every $10 \mathrm{Mg} \mathrm{ha}^{-1}$ described by Donato (2011) and Santos et al. (2002), respectively. For Dubeux Júnior \& Santos (2005), K and Ca are the nutrients exported in highest amounts by the crop. Although the utilized P source, single superphosphate, contains $\mathrm{Ca}$, the low applied amount, its mean contents in the soil and the soil buffering capacity maintain plant production; in spite of that, the extraction is low, a consequence of the availability.

Sulfur - The extraction/export of S in the treatments NP and NPK were 100.53 and $100.51 \mathrm{~kg} \mathrm{ha}^{-1}$, respectively, which were higher than those for the treatment without fertilization (17.12 $\left.\mathrm{kg} \mathrm{ha}^{-1}\right)$ and fertilized only with P (31.29 $\left.\mathrm{kg} \mathrm{ha}^{-1}\right)$. The addition of $\mathrm{S}$ was not the goal, but the sources of $\mathrm{N}$ and $\mathrm{P}$ (ammonium sulfate, $\left(\mathrm{NH}_{4}\right)_{2} \mathrm{SO}_{4}, 20 \%$ of $\mathrm{N}+24 \%$ of $\mathrm{S}$ and single superphosphate $\left(\mathrm{Ca}\left(\mathrm{H}_{3} \mathrm{PO}_{4}\right)_{2} \cdot \mathrm{H}_{2} \mathrm{O}+\mathrm{CaSO}_{4} 2 \mathrm{H}_{2} \mathrm{O}, 18 \%\right.$ of $\mathrm{P}_{2} \mathrm{O}_{5}$ $+18 \%$ of $\mathrm{Ca}+11 \%$ of $\mathrm{S}$ ), indirectly added $\mathrm{S}$, which was greater supply for the treatments NPK and NP, increasing S contents in the soil, thus leading to greater extraction/export. The obtained mean, $62.35 \mathrm{~kg} \mathrm{ha}^{-1}$, is superior to the mean extraction/export of $33.7 \mathrm{~kg} \mathrm{ha}^{-1}$ observed in the study of Donato (2011).

Magnesium - The extraction/export of $\mathrm{Mg}$ was dependent on the interaction $(\mathrm{p}<0.05)$ between the spacings and the types of chemical fertilizations used (Table 2).

In the spacing $S_{1}$, for the fertilizations $\mathrm{P}, \mathrm{NP}$ and NPK, the mean extractions/exports of $\mathrm{Mg}$ were 253.46, 267.86 and $248.73 \mathrm{~kg} \mathrm{ha}^{-1}$, respectively, higher than $140.08 \mathrm{~kg} \mathrm{ha}^{-1}$ for the treatment without fertilization. Although $\mathrm{Mg}$ is not supplied through the fertilizations, the synergetic interaction of applied P x soil Mg favors the absorption of both (Lana et al., 2004). For the other spacings, $\mathrm{S}_{2}$ and $\mathrm{S}_{3}$, the means were similar as a function of the fertilizations.

When NP fertilization was used, the mean extraction/ export of $\mathrm{Mg}$, obtained at the spacing $\mathrm{S}_{1}$ was $267.86 \mathrm{~kg} \mathrm{ha}^{-1}$, statistically superior to that obtained in the spacing $\mathrm{S}_{2}(176.96$ $\left.\mathrm{kg} \mathrm{ha}^{-1}\right)$ and similar to that obtained in the spacing $\mathrm{S}_{3}(182.05$ $\mathrm{kg} \mathrm{ha}^{-1}$ ); for these two treatments, no difference was observed between the fertilizations. With overall mean value of $215.77 \mathrm{~kg} \mathrm{ha}^{-1}$, the extraction/export of $\mathrm{Mg}$ in the present study was close to that found by Donato (2011), who observed mean extraction of $207.1 \mathrm{~kg} \mathrm{ha}^{-1}$.

Micronutrients - The extraction/export of Mn differed ( $p<0.05)$ independently, for both factors, fertilization and spacing. For $\mathrm{Cu}$, however, regardless of the adopted plant spacing, there was significant effect only for fertilization. For the other elements ( $\mathrm{B}, \mathrm{Fe}, \mathrm{Zn}$ and $\mathrm{Na}$ ), no significant difference was observed for the tested factors (Table 3 ).

The extraction/export of $\mathrm{Cu}$ by cactus pear plants fertilized with NPK was similar to that of plants under NP and higher than that of plants fertilized with $\mathrm{P}$ and without fertilization. The mean extraction/export of $0.08 \mathrm{~kg} \mathrm{ha}^{-1}$ was similar to the mean $\left(0.07 \mathrm{~kg} \mathrm{ha}^{-1}\right)$ obtained by Donato (2011).

The extractions/exports of $\mathrm{Mn}, 16.27$ and $11.12 \mathrm{~kg} \mathrm{ha}^{-1}$, for the treatments without fertilization and with $\mathrm{P}$, respectively, are similar and were lower than 30.39 and $37.16 \mathrm{~kg} \mathrm{ha}^{-1}$, obtained with the treatments NP and NPK, which also differed; in most cases, soil $\mathrm{pH}$ is the factor that most influences the availability of $\mathrm{Mn}$ to plants. The increase of soil $\mathrm{pH}$ in one unit reduces about 100 times the Mn concentration in the soil solution (Mortvedt, 2001). The use of ammonium sulfate promotes a reduction in the $\mathrm{pH}$ of the environment, which increases the solubility and the consequent absorption of $\mathrm{Mn}^{2+}$. This fact explains the differences between treatments and is evidenced

Table 2. Extraction/export of magnesium $\left(\mathrm{kg} \mathrm{ha}^{-1}\right)$ by cactus pear harvested 620 days after planting, under different spacings and chemical fertilizations

\begin{tabular}{|c|c|c|c|c|c|c|}
\hline \multirow{3}{*}{ Spacing (m) } & \multicolumn{5}{|c|}{ Extraction/export of $\mathrm{Mg}$} & \multirow{3}{*}{$\begin{array}{l}\text { CV } \\
(\%)\end{array}$} \\
\hline & \multicolumn{5}{|c|}{ 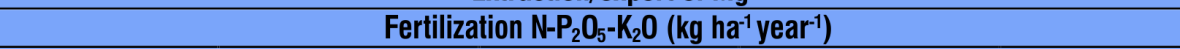 } & \\
\hline & $000-000-000$ & 000-150-000 & $200-150-000$ & $200-150-100$ & Mean & \\
\hline$S_{1}-1.00 \times 0.50$ & $140.08 \mathrm{Ab}$ & $253.46 \mathrm{Aa}$ & $267.86 \mathrm{Aa}$ & $248.73 \mathrm{Aa}$ & 227.53 & \multirow{4}{*}{19.51} \\
\hline$S_{2}-2.00 \times 0.25$ & $224.96 \mathrm{Aa}$ & $196.74 \mathrm{Aa}$ & $176.96 \mathrm{Ba}$ & $232.68 \mathrm{Aa}$ & 207.84 & \\
\hline$S_{3}-3.00 \times 1.00 \times 0.25$ & $209.41 \mathrm{Aa}$ & $262.56 \mathrm{Aa}$ & $182.05 \mathrm{ABa}$ & $193.68 \mathrm{Aa}$ & 211.93 & \\
\hline Mean & 191.48 & 237.59 & 208.96 & 225.03 & 215.77 & \\
\hline
\end{tabular}

Means followed by the same letter, lowercase in the rows and uppercase in the columns, do not differ significantly by Tukey test at 0.05 probability level 
Table 3. Mean extraction/export of micronutrients $\left(\mathrm{kg} \mathrm{ha}^{-1}\right)$ by cactus pear harvested 620 days after planting, under different spacings and chemical fertilizations

\begin{tabular}{|c|c|c|c|c|c|c|c|c|c|}
\hline \multirow{2}{*}{ Variables } & \multicolumn{4}{|c|}{ Fertilization $\mathrm{N}-\mathrm{P}_{2} \mathrm{O}_{5}-\mathrm{K}_{2} \mathrm{O}\left(\mathrm{kg} \mathrm{ha}^{-1} \text { year }{ }^{-1}\right)^{\#}$} & \multicolumn{3}{|c|}{ Spacing $(\mathrm{m})$} & \multirow{2}{*}{ Mean } & \multirow{2}{*}{$\begin{array}{l}\text { CV } \\
(\%)\end{array}$} \\
\hline & $0-0-0$ & $0-P-0$ & $\mathrm{~N}-\mathrm{P}-\mathrm{O}$ & N-P-K & $S_{1}$ & $S_{2}$ & $\mathrm{~S}_{3}$ & & \\
\hline $\mathrm{B}$ & $0.38 \mathrm{~A}$ & $0.38 \mathrm{~A}$ & $0.37 \mathrm{~A}$ & $0.43 \mathrm{~A}$ & $0.44 \mathrm{~A}$ & $0.39 \mathrm{~A}$ & $0.34 \mathrm{~A}$ & 0.39 & 28.85 \\
\hline $\mathrm{Cu}$ & $0.07 \mathrm{~B}$ & $0.07 \mathrm{~B}$ & $0.09 \mathrm{AB}$ & $0.10 \mathrm{~A}$ & $0.07 \mathrm{~A}$ & $0.08 \mathrm{~A}$ & $0.08 \mathrm{~A}$ & 0.08 & 18.99 \\
\hline $\mathrm{Fe}$ & $0.64 \mathrm{~A}$ & $0.85 \mathrm{~A}$ & $0.81 \mathrm{~A}$ & $0.93 \mathrm{~A}$ & $0.93 \mathrm{~A}$ & $0.78 \mathrm{~A}$ & $0.72 \mathrm{~A}$ & 0.81 & 34.74 \\
\hline $\mathrm{Mn}$ & $16.27 \mathrm{~B}$ & $11.12 \mathrm{~B}$ & $30.39 \mathrm{~A}$ & $37.16 \mathrm{~A}$ & $28.23 \mathrm{~A}$ & $23.00 \mathrm{~B}$ & $19.98 \mathrm{C}$ & 23.74 & 26.74 \\
\hline $\mathrm{Zn}$ & $0.98 \mathrm{~A}$ & $0.98 \mathrm{~A}$ & $1.24 \mathrm{~A}$ & $1.23 \mathrm{~A}$ & $1.11 \mathrm{~A}$ & $1.12 \mathrm{~A}$ & $1.10 \mathrm{~A}$ & 1.11 & 18.93 \\
\hline $\mathrm{Na}$ & $0.72 \mathrm{~A}$ & $0.63 \mathrm{~A}$ & $0.52 \mathrm{~A}$ & $0.61 \mathrm{~A}$ & $0.73 \mathrm{~A}$ & $0.69 \mathrm{~A}$ & $0.64 \mathrm{~A}$ & 0.62 & 33.73 \\
\hline
\end{tabular}

\# Fertilization in $\left(\mathrm{kg} \mathrm{ha}^{-1}\right.$ year $\left.^{-1}\right) \mathrm{N}-\mathrm{P}_{2} \mathrm{O}_{5}-\mathrm{K}_{2} 0$ : 000-000-000; 000-150-000; 200-150-000 and 200-150-100

Spacing: $\mathrm{S}_{1}-1.0 \times 0.5 \mathrm{~S}_{2}-2.0 \times 0.5 ; \mathrm{S}_{3}-3 \times 1 \times 0.25$

Means followed by the same uppercase letter in the rows do not differ significantly by Tukey test at 0.05 probability level

by the comparison of $\mathrm{pH}$ before planting (5.33) and after the applications during the evaluation period: $\mathrm{pH}$ - $600 \mathrm{DAP}$, without fertilization, 4.99; P, 4.78; NP, 4.16; NPK, 4.29. Lower $\mathrm{pH}$ values were observed, especially when ammonium sulfate was used (NP and NPK) and, in general, it is due to the absorption of nutrients by the crop, with consequent extrusion of protons.

The effect of spacings on the extraction/export of $\mathrm{Mn}$ decreased for the spacings $\mathrm{S}_{1}, \mathrm{~S}_{2}$ and $\mathrm{S}_{3}$, showing mean values of $28.23,23.00$ and $19.98 \mathrm{~kg} \mathrm{ha}^{-1}$, respectively. The overall mean extraction/export of $23.74 \mathrm{~kg} \mathrm{ha}^{-1}$, resulting from the different treatments, was superior to $12.07 \mathrm{~kg} \mathrm{ha}^{-1}$, observed by Donato (2011).

Without any significant differences, the mean extractions/ exports of B $\left(0.39 \mathrm{~kg} \mathrm{ha}^{-1}\right)$, Fe $\left(0.81 \mathrm{~kg} \mathrm{ha}^{-1}\right), \mathrm{Zn}\left(1.11 \mathrm{~kg} \mathrm{ha}^{-1}\right)$ and $\mathrm{Na}\left(0.62 \mathrm{~kg} \mathrm{ha}^{-1}\right)$ are slightly lower than the respective mean values of $0.56,1.33,1.15$ and $0.84 \mathrm{~kg} \mathrm{ha}^{-1}$, reported by Donato (2011).

Dry matter production - Dry matter production, quantified at 620 DAP at the harvest, was dependent on the interaction $(\mathrm{p}<0.05)$ between the plant spacing and the adopted chemical fertilization (Table 4).

The mean dry matter production was $17.10 \mathrm{Mg} \mathrm{ha}^{-1}$. Plants cultivated in the spacing $S_{1}$ and fertilized with NPK, NP and $P$ produced more dry matter $(\mathrm{p}<0.05)$ compared with plants without fertilization.

Plants without fertilization produced more dry matter ( $\mathrm{p}$ $<0.05)$ in the spacing of $2.0 \times 0.25 \mathrm{~m}$, compared with $1.0 \mathrm{x}$ $0.5 \mathrm{~m}$. On the other hand, plants fertilized with NPK and NP produced larger amount of dry matter at the spacing of $1.0 \times 0.5$ $\mathrm{m}$, but when fertilized with only $\mathrm{P}$, the dry matter production was similar for the three spacings. Dubeux Júnior et al. (2006) observed influence of plant population on yield, in various localities, with dry matter ranging from 6 to $17 \mathrm{Mg} \mathrm{ha}^{-1}$ for 5,000 plants ha-1 $(2.00 \times 1.00 \mathrm{~m})$ and 17.8 to $33.7 \mathrm{Mg} \mathrm{ha}^{-1}$ in 40,000 plants ha- ${ }^{-1}(1.00 \times 0.25 \mathrm{~m})$. Alves et al. (2007) obtained 5.6 $\mathrm{Mg} \mathrm{ha}^{-1}$ of dry matter without effect of spacing for 5,000 and 10,000 plants ha ${ }^{-1}$. Evaluating fertilizations with $\mathrm{P}$ and $\mathrm{K}$ in cactus pear cv. Clone IPA-20, Dubeux Júnior et al. (2010) found effect of $\mathrm{K}$ on the production of green mass and dry matter.

\section{Extraction/export of macronutrients $x$ supply}

According to the comparison between the amounts of supplied and extracted/exported nutrients (Table 5), N, K, $\mathrm{Ca}$ and $\mathrm{Mg}$ showed deficit in relation to the supplies through fertilization for most of the tested treatments, indicating that the applied doses are not sufficient for the plant to express its production potential. With the continuation of the cultivation, it is probable that the reserves of the soil decrease and compromise even more crop yield and longevity, requiring higher doses for full production. In the balance of macronutrients, only the nutrients applied through fertilization are considered, disregarding those from the soil. This extraction was possible because of the buffering capacity of these nutrients in the soil, i.e., through the power of replenishment of nutrients to the soil solution, by the reserve of the solid phase of the soil (Novais \& Mello, 2007). For S and P, however, with a positive balance, maintaining the fertilizations, there will be no problem of excess, due to the maximum adsorption capacity of the soil (Novais \& Mello, 2007).

With decreasing order of extraction/export (Ca, K, N, Mg, $\mathrm{S}$ and $\mathrm{P}$ ), the results obtained in the present study differed from those of Donato (2011) and Teles et al. (2004), which showed the following decreasing sequence of extraction: $\mathrm{K}, \mathrm{Ca}, \mathrm{N}$, $\mathrm{Mg}, \mathrm{P}$ and S. However, it was similar to the order of contents of macronutrients in cladodes found by Silva et al. (2012). The low supply of $\mathrm{K}$ through fertilization justifies the results.

\section{Extraction/export of micronutrients $x$ supply}

Since the fertilization formulations used did not have micronutrients, all the treatments showed negative balance (Table 6), indicating the need for the application of these nutrients in order to preserve the reserves of the soil and guarantee an ideal supply for the crop to express its production potential. The micronutrients showed a decreasing order

Table 4. Dry matter production (Mg ha-1) 620 days after planting of the cactus pear subjected to different spacings and chemical fertilizations

\begin{tabular}{|c|c|c|c|c|c|}
\hline \multirow{2}{*}{ Spacing (m) } & \multicolumn{4}{|c|}{ Fertilization $\mathrm{N}-\mathrm{P}_{2} \mathrm{O}_{5}-\mathrm{K}_{2} \mathrm{O}\left(\mathrm{kg} \mathrm{ha}^{-1}\right.$ year $\left.^{-1}\right)$} & \multirow{2}{*}{ CV (\%) } \\
\hline & $000-000-000$ & $000-150-000$ & $200-150-000$ & $200-150-100$ & \\
\hline$S_{1}-1.00 \times 0.50$ & $13.40 \mathrm{bB}$ & $19.38 \mathrm{aA}$ & $20.87 \mathrm{aA}$ & $22.73 \mathrm{aA}$ & \\
\hline$S_{2}-2.00 \times 0.25$ & $18.11 \mathrm{aA}$ & $14.87 \mathrm{aA}$ & $16.12 \mathrm{aB}$ & $18.24 \mathrm{aB}$ & 15.36 \\
\hline$S_{3}-3.00 \times 1.00 \times 0.25$ & $14.13 \mathrm{aAB}$ & $16.05 \mathrm{aA}$ & $15.67 \mathrm{aB}$ & $15.68 \mathrm{aB}$ & \\
\hline
\end{tabular}

Means followed by the same letter, lowercase in the row and uppercase in the column, do not differ significantly by Duncan test at 0.05 probability level 
Table 5. Balance of macronutrients (nitrogen, phosphorus, potassium, calcium, magnesium and sulfur) as a function of the extraction/export by the cactus pear and the amount added to the soil through NPK fertilization 620 days after planting

\begin{tabular}{|c|c|c|c|c|c|}
\hline & \multicolumn{4}{|c|}{ Types of fertilization $\mathrm{N}-\mathrm{P}_{2} \mathrm{O}_{5}-\mathrm{K}_{2} \mathrm{O}\left(\mathrm{kg} \mathrm{ha}^{-1} \mathrm{year}^{-1}\right)^{\star}$} & \multirow{2}{*}{ Mean } \\
\hline & $000-000-000$ & $000-150-000$ & $200-150-000$ & $200-150-100$ & \\
\hline Nitrogen extracted/exported (kg ha') & 180.20 & 232.80 & 391.00 & 413.40 & 304.35 \\
\hline Nitrogen added $\left(\mathrm{kg} \mathrm{ha}^{-1}\right)$ & 0.00 & 0.00 & 400.00 & 400.00 & \\
\hline Balance of nitrogen $\left(\mathrm{kg} \mathrm{ha}^{-1}\right)$ & -180.20 & -232.80 & 9.00 & -13.40 & \\
\hline Phosphorus extracted/exported (kg ha') & 12.37 & 20.16 & 20.74 & 21.95 & 18.81 \\
\hline Phosphorus added (kg ha') & 0.00 & 129.00 & 129.00 & 129.00 & \\
\hline Balance of phosphorus (kg ha-1) & -12.37 & 109.00 & 108.26 & 107.05 & \\
\hline Potassium extracted/exported (kg ha') & 393.72 & 401.44 & 384.98 & 504.01 & 421.04 \\
\hline Potassium added $\left(\mathrm{kg} \mathrm{ha}^{-1}\right)$ & 0.00 & 0.00 & 0.00 & 166.00 & \\
\hline Balance of potassium $\left(\mathrm{kg} \mathrm{ha}^{-1}\right)$ & -393.72 & -401.44 & -384.98 & -338.01 & \\
\hline Calcium extracted/exported (kg ha') & 444.07 & 505.06 & 431.89 & 476.71 & 464.43 \\
\hline Calcium added $\left(\mathrm{kg} \mathrm{ha}^{-1}\right)$ & 0.00 & 266.66 & 266.66 & 266.66 & \\
\hline Balance of calcium (kg ha') & -444.07 & -238.40 & -165.23 & -210.05 & \\
\hline Magnesium extracted/exported (kg ha') & 191.48 & 237.59 & 208.96 & 237.03 & 218.77 \\
\hline Magnesium added $\left(\mathrm{kg} \mathrm{ha}^{-1}\right)$ & 0.00 & 0.00 & 0.00 & 0.00 & \\
\hline Balance of magnesium (kg ha-1) & -191.48 & -237.59 & -208.96 & -237.03 & \\
\hline Sulfur extracted/exported (kg ha') & 17.12 & 31.29 & 100.53 & 100.51 & 62.36 \\
\hline Sulfur added $\left(\mathrm{kg} \mathrm{ha}^{-1}\right)$ & 0.00 & 133.30 & 613.30 & 613.30 & \\
\hline Balance of sulfur $\left(\mathrm{kg} \mathrm{ha}^{-1}\right)$ & -17.12 & 102.01 & 512.77 & 512.79 & \\
\hline Dry matter production (Mg ha-1) & 15.21 & 16.77 & 17.58 & 18.88 & 17.11 \\
\hline
\end{tabular}

* The supply corresponds to two years of application

Table 6. Balance of micronutrients (boron, copper, iron, manganese, sodium and zinc) as a function of the extraction/ export by cactus pear and the amount added to the soil through NPK fertilization 620 days after planting

\begin{tabular}{|c|c|c|c|c|c|}
\hline & \multicolumn{4}{|c|}{ Types of fertilization $\mathrm{N}-\mathrm{P}_{2} \mathrm{O}_{5}-\mathrm{K}_{2} \mathrm{O}\left(\mathrm{kg} \mathrm{ha}^{-1} \text { year }^{-1}\right)^{*}$} & \multirow{2}{*}{ Mean } \\
\hline & $000-000-000$ & $000-150-000$ & $200-150-000$ & $200-150-100$ & \\
\hline Boron extracted/exported (kg ha') & 0.38 & 0.38 & 0.37 & 0.43 & 0.39 \\
\hline Boron added $\left(\mathrm{kg} \mathrm{ha}^{-1}\right)$ & 0.00 & 0.00 & 0.00 & 0.00 & \\
\hline Balance of boron ( $\left.\mathrm{kg} \mathrm{ha})^{-1}\right)$ & -0.38 & -0.38 & -0.37 & -0.43 & \\
\hline Copper extracted/exported (kg ha') & 0.07 & 0.07 & 0.09 & 0.10 & 0.08 \\
\hline Copper added $\left(\mathrm{kg} \mathrm{ha}^{-1}\right)$ & 0.00 & 0.00 & 0.00 & 0.00 & \\
\hline Balance of copper ( $\left.\mathrm{kg} \mathrm{ha}^{-1}\right)$ & -0.07 & -0.07 & -0.09 & -0.10 & \\
\hline Iron extracted/exported (kg ha') & 0.64 & 0.85 & 0.81 & 0.93 & 0.81 \\
\hline Iron added $\left(\mathrm{kg} \mathrm{ha}^{-1}\right)$ & 0.00 & 0.00 & 0.00 & 0.00 & \\
\hline Balance of iron $\left(\mathrm{kg} \mathrm{ha}^{1}\right)$ & -0.64 & -0.85 & -0.81 & -0.93 & \\
\hline Manganese extracted/exported (kg ha') & 16.27 & 11.12 & 30.29 & 37.16 & 23.71 \\
\hline Manganese added $\left(\mathrm{kg} \mathrm{ha}^{-1}\right)$ & 0.00 & 0.00 & 0.00 & 0.00 & \\
\hline Balance of manganese $\left(\mathrm{kg} \mathrm{ha}^{-1}\right)$ & -16.27 & -11.12 & -30.29 & -37.16 & \\
\hline Sodium extracted/exported (kg ha') & 0.72 & 0.63 & 0.52 & 0.61 & 0.62 \\
\hline Sodium added $\left(\mathrm{kg} \mathrm{ha}^{-1}\right)$ & 0.00 & 0.00 & 0.00 & 0.00 & \\
\hline Balance of sodium $\left(\mathrm{kg} \mathrm{ha}^{-1}\right)$ & -0.72 & -0.63 & -0.52 & -0.61 & \\
\hline Zinc extracted/exported (kg ha') & 0.98 & 0.98 & 1.24 & 1.23 & 1.11 \\
\hline Zinc added $\left(\mathrm{kg} \mathrm{ha}^{-1}\right)$ & 0.00 & 0.00 & 0.00 & 0.00 & \\
\hline Balance of zinc ( $\left.\mathrm{kg} \mathrm{ha}^{-1}\right)$ & -0.98 & -0.98 & -1.24 & -1.23 & \\
\hline Dry matter production (Mg ha') & 15.21 & 16.77 & 17.58 & 18.88 & 17.11 \\
\hline
\end{tabular}

of extraction/export: $\mathrm{Mn}, \mathrm{Zn}, \mathrm{Fe}, \mathrm{Na}, \mathrm{B}$ and $\mathrm{Cu}$. Similar relationships for micronutrients were reported by Silva et al. (2012) and Dubeux Júnior et al. (2010).

\section{Conclusions}

1. The evaluated fertilizations did not meet the demands of the crop, which showed negative balance of $\mathrm{N}, \mathrm{K}, \mathrm{Ca}, \mathrm{Mg}$ and all the micronutrients.

2. The fertilizations increased the extractions of nutrients, especially $\mathrm{N}, \mathrm{P}$ and $\mathrm{S}$, at the spacing of $1.00 \times 0.50 \mathrm{~m}$, and increased dry matter production.

3. The decreasing orders of extraction/export by the cactus pear were $\mathrm{Ca}, \mathrm{K}, \mathrm{N}, \mathrm{Mg}, \mathrm{S}$ and $\mathrm{P}$, for macronutrients, and $\mathrm{Mn}$, $\mathrm{Zn}, \mathrm{Fe}, \mathrm{Na}, \mathrm{B}$ and $\mathrm{Cu}$, for micronutrients.

\section{Literature Cited}

Alves, R. N.; Farias, I.; Menezes, R. S. C.; Lira. M. de A.; Santos, D. C. dos. Produção de forragem pela palma após 19 anos com diferentes intensidades de corte e espaçamentos. Caatinga, v.20, p.38-44, 2007.

Araújo, L. F. Oliveira, L. S. C.; Perazzo Neto, A.; Alsina, L. O. S.; Silva, F. L. H. da. Equilíbrio higroscópico da palma forrageira: Relação com a umidade ótima para fermentação sólida. Revista Brasileira de Engenharia Agrícola e Ambiental, v.9, p.379-384, 2005. http:// dx.doi.org/10.1590/S1415-43662005000300013

Blanco-Macías, F.; Magallanes-Quintanar, R.; Valdez-Cepeda, R. D.; Vázquez-Alvarado, R.; Olivares-Sáenz, E.; Gutiérrez-Ornelas, E.; Vidales-Contreras, J. A.; Murillo-Amador, B. Nutritional reference values for Opuntia ficus-indica determined by means of the boundary-line approach. Journal of Plant Nutrition Soil Science, v.173, p.927-934, 2010. http://dx.doi.org/10.1002/jpln.200900147 
Donato, P. E. R. Avaliação bromatológica, morfológica, nutricional e de rendimento em palma forrageira sob diferentes espaçamentos e doses de esterco bovino. Itapetinga: UESB, 2011. 134p. Tese Doutorado

Donato, P. E. R.; Pires, A. J. V.; Donato, S. L. R.; Bonomo, P.; Silva, J. A.; Aquino, A. A. Morfometria e rendimento da palma forrageira 'Gigante' sob diferentes espaçamentos e doses de adubação orgânica. Revista Brasileira de Ciências Agrárias v.9, p.151-158, 2014a. http://dx.doi.org/10.5039/agraria.v9i1a3252

Donato, P. E. R.; Pires, A. J. V.; Donato, S. L. R.; Silva, J. A.; Aquino, A. A. Valor nutritivo da palma forrageira 'Gigante' cultivada sob diferentes espaçamentos e doses de esterco bovino. Caatinga, v.27, p.163 -172, 2014b.

Dubeux Júnior, J. C. B.; Araújo Filho, J. T.; Santos, M. V. F dos. ; Lira. M de A.; Santos, D. C. dos; Pessoa, R. A. S. Adubação mineral no crescimento e composição mineral da palma forrageira - Clone IPA-20. Revista Brasileira de Ciências Agrárias, v.5, p.129-135, 2010. http://dx.doi.org/10.5039/agraria.v5ila591

Dubeux Júnior, J. C. B.; Santos, M. V. F. dos. Exigências nutricionais da palma forrageira. In: Menezes, R. S. C.; Simões, D. A.; Sampaio, E.V.S.B. (ed.). A palma no Nordeste do Brasil: Conhecimento atual e novas perspectivas de uso. 2.ed. Recife: UFPE, 2005. p.105-128.

Dubeux Júnior, J. C. B.; Santos, M. V. F. dos; Lira, M. A. Productivity of Opuntia ficus-indica (L.) Miller under different $\mathrm{N}$ and $\mathrm{P}$ fertilization and plant population in north-east Brazil. Journal of Arid Environments, v.67, p.357-372, 2006. http://dx.doi. org/10.1016/j.jaridenv.2006.02.015

Espinoza, F. H. R.; Mendoza, J. F. A.; Amador, B. M; Hernández, L. G.; Lara, R. P.; Osuna, J. de D. D.; Morales, F. A. B.; Larios, L. F. Rendimiento y crecimiento de nopalitos de cultivares de nopal (Opuntia ficusindica) bajodiferentes densidades de plantación. Journal Professional Association for Cactus Development, v.10, p.22-35, 2008.

Fialho, J. S.; Aguiar, M. I.; Maia, L. S.; Magalhães, R. B.; Araújo, F. C. S.; Campanha, M. M.; Oliveira, T. S. Soil quality, resistance and resilience in traditional agricultural and agroforestry ecosystems in Brasil's semiarid region. African Journal of Agricultural Research, v.8, p.5020-5031, 2013. http://dx.doi.org/ 10.5897/AJAR2013.6712

Germano, R. H.; Barbosa, H. P.; Costa, R. G.; Medeiros, V. N.; Carvalho, F. F. R. Avaliação da composição química e mineral de seis cactáceas do semiárido paraibano. Revista Agropecuária Técnica, v.20, p.51-57, 1999.

Lana, R. M. Q.; Zanão Júnior, L. A.; Luz, J. M. Q.; Silva, J. C. Produção da alface em função do uso de diferentes fontes de fósforo em solo de Cerrado. Horticultura Brasileira, Brasília, v.22, p.525-528, 2004. http://dx.doi.org/10.1590/S0102-05362004000300004

Mortvedt, J. J. Tecnologia e produção de fertilizantes com micronutrientes: presença de elementos tóxicos. In: Ferreira, M. E.; Cruz, M. C. P.; Raij, B. van; Abreu, C. A. (ed.). Micronutrientes e elementos tóxicos na agricultura. Jaboticabal: CNPq/FAPESP/POTAFOS, 2001. p.237-251.
Novais, R. F.; Mello, J. W. V. Relação solo-planta. In: Novais, R. F.; Alvarez V., V. H.; Barros, N. F.; Fontes, L. E. F.; Neves, J. C. L. (ed.). Fertilidade do solo. 1.ed. Viçosa: Sociedade Brasileira de Ciência do Solo, 2007. p.133-204.

Ramos, J. P. F; Leite, M. L. M.V.; Oliveira Júnior, S.; Nascimento, J. P.; Santos, E. M. Crescimento vegetativo de Opuntia fícusindica em diferentes espaçamentos de plantio. Caatinga, v.24, p.41-48, 2011.

Santos, D. C.; Farias, I.; Lira, M. A. Manejo e utilização da palma forrageira (Opuntia e Nopalea) em Pernambuco. Recife: IPA, 2006. 48p.

Santos, D. C.; Farias, I.; Lira, M. A.; Santos, M. V. F.; Arruda, G. P.; Coelho R. S. B.; Dias, F. M.; Warumby, J. F.; Melo, J. N. Manejo e utilização da palma forrageira (Opuntia e Nopalea) em Pernambuco: Cultivo e utilização. Recife: IPA, 2002. 45p.

Silva, D. J.; Queiroz, A. C. Análise de alimentos: métodos químicos e biológicos. 3.ed. Viçosa: UFV, 2009. 235p.

Silva, J. A.; Bonomo, P., Donato, S. L. R.; Pires, A. J. V.; Rosa, R. C. C.; Donato, Paulo E. R. Composição mineral em cladódios de palma forrageira sob diferentes espaçamentos e adubações química. Revista Brasileira de Ciências Agrárias, v.7, p.866-875, 2012. http://dx.doi.org/10.5039/agraria.v7isa2134

Silva, J. A.; Bonomo, P., Donato, S. L. R.; Pires, A. J. V.; Silva, F. F.; Donato, Paulo E.R. Composição bromatológica de cladódios de palma forrageira sob diferentes espaçamentos e adubações químicas. Revista Brasileira de Ciências Agrárias, v.8, p.342-350, 2013. http://dx.doi.org/10.5039/agraria.v8i2a2431

Silva, L. M.; Fagundes, J. L.; Viegas, P. A. A.; Muniz, E. N.; Rangel, J. H.; Moreira, A. L.; Backes, A. C. Produtividade da palma forrageira cultivada em diferentes densidades de plantio. Ciência Rural, v.44, p.2064-2071, 2014. http://dx.doi.org/10.1590/0103$8478 \mathrm{cr} 20131305$

Stewart, W. M.; Dibb, D.W.; Johnston, A. E.; Smyth, T. J. Contribution of commercial fertilizer nutrients to food production. Agronomy Journal, v.97, p.1-6, 2005. http://dx.doi.org/10.2134/ agronj2005.0001

Teles, M. M.; Santos, M. V. F.; Dubeux Júnior, J. C. B.; Lira, M. A.; Ferreira, R. L. C.; Bezerra Neto, E. C.; Farias, I. Efeito da adubação e do uso de nematicida na composição química da palma forrageira (Opuntia ficus indica, Mill). Revista Brasileira de Zootecnia, v.33, p.1992-1998, 2004. http://dx.doi.org/10.1590/ S1516-35982004000800010

Zañudo-Hernández, J.; Aranda E. G. C.; Ramírez-Hernández, B. C.; Pimienta-Barrios, E.; Castillo-Cruz, I,; Pimienta-Barrios, E. Ecophysiological responses of Opuntia to water stress under various semi-arid environments. Journal PACD, v,12, p.20-36, 2010. 